\title{
Zero-Leverage Policy: Is the Family Nature of Private Firms Relevant?
}

\author{
Oscar Domenichelli ${ }^{1}$ \\ 1 Department of Management, Faculty of Economics "Giorgio Fuà", Università Politecnica delle Marche, \\ Ancona, Italy \\ Correspondence: Oscar Domenichelli, Department of Management, Faculty of Economics "Giorgio Fuà", \\ Università Politecnica delle Marche, Piazzale R. Martelli, 8, 60121, Ancona, Italy. Tel: 390-712-207-193. E-mail: \\ o.domenichelli@staff.univpm.it
}

Received: April 19, 2019

Accepted: May 17, 2019

Online Published: May 28, 2019

doi:10.5539/ijef.v11n7p28

URL: https://doi.org/10.5539/ijef.v11n7p28

\begin{abstract}
This work investigates whether being a family business influences a private firm's propensity to be leveraged and the underlying reasons behind such propensity. Analysis focuses on a sample of Italian private family and non-family firms for the period from 2008-2017. Socioemotional and corporate governance considerations cause agency conflicts to be negligible in Italian private family firms, and thus the use of debt is unrelated to these conflicts. Nevertheless, these enterprises are more likely to eschew a zero-debt policy, as opposed to their non-family counterparts. This is due to the socioemotional orientation of Italian private family firms, that is the desire of their family owners to keep long-term control over the business, through the use of leverage, which prevails over risk aversion.
\end{abstract}

Keywords: zero-leverage policy, private family and non-family firms, agency conflicts, socioemotional wealth

\section{Introduction}

One of the puzzling issues in corporate finance concerns the presence of zero-leverage firms around the world. (Dang, 2013; Strabulaev \& Yang, 2013; Bessler et al., 2013; Li et al., 2015). Several explanations have been proposed to justify this phenomenon, such as financial constraints (Devos et al., 2012; Dang, 2013; Bessler et al, 2013; Huang et al., 2017), financial flexibility (Dang, 2013; Bessler et al., 2013; Ferrão et al., 2016; Huang et al., 2017), trade-off theory, pecking order theory (Dang, 2013; Ramalho et al., 2018), and agency costs (Strabulaev \& Yang, 2013; Ramalho et al., 2018). Financial constraints arise from the presence of imperfect capital markets and thus asymmetric information, since lenders are not able to effectively evaluate the firm's quality and the quality of its investments (Stiglits \& Weiss, 1981). Therefore, financially constrained firms are underlevered compared to their unconstrained counterparts (Dang, 2013). Previous research documents that, as young and small firms mature and grow, financial constraints tend to diminish (Hadlock \& Pierce, 2010), and hence they can obtain debt financing more easily. The issue of financial flexibility concerns the ability of a firm to suitably change its capital structure. As a result, firms with considerable expected investments become debt free in order to avoid financing them with new risky securities or even being forced to forgo them (Bessler et al., 2013). Therefore, financial flexibility can both help diminish the costs associated with financial distress and mitigate underinvestment problems in the case of restricted access to capital (Rapp et al., 2014). In the context of the trade-off theory, firms balance the benefit of debt financing with its cost (Kraus \& Litzenberger, 1973), whereas according to the pecking order theory (Myers, 1984; Myers \& Majluf, 1984), firms prefer those sources of financing which minimize the costs generated by the asymmetric information, which affect outside investors. Hence, the tendency of a firm to be zero-levered is influenced by the determinants of capital structures, which the aforementioned theories consider. Furthermore, agency costs (Ross, 1973; Myers, 1977; Smith \& Warner, 1979; Mork et al., 1988) and related corporate governance implications can also determine the likelihood of a business to use debt (Strabulaev \& Yang, 2013; Ramalho et al., 2018).

So far, there is scant empirical evidence on zero-debt family firms. The existing studies refer only to large public family businesses or family firms as opposed to non-family firms of different sizes. Strebulaev and Yang (2013) analyse large public nonfinancial US companies and conclude that, owing to their desire for long-term survival, increasing the perceived risk of default, family businesses are more likely to be zero-levered, whereas Ramalho 
et al. (2018), in a study of family and non-family firms of micro, small, and large sizes in Portugal, find that family ownership influences positively the probability of firms using debt, specifically when the firm is large or located in a metropolitan area. In my view, this limited and contradictory evidence on the zero-debt orientation of family firms deserves further investigation; thus, this paper examines Italian private family and non-family businesses. Moreover, this work, to the best of my knowledge, is the first to analyse the propensity to adopt a zero-debt policy by private family firms versus private non-family firms in a bank-oriented economy, such as Italy.

The interest in focusing on the previously mentioned topic concerns the peculiarities of the businesses being studied. First, private (family) firms have equity shares which are not traded in a stock exchange, and they are allowed to release only basic information about their financial situation and performance. Privately held family firms also benefit from the absence of the capital market discipline, which enables them to satisfy their long-term orientation and enhance their socioemotional attitude (Carney et al., 2015). Secondly, family firms, the majority of which are unlisted, represent more than 70 percent of industrial and services businesses in Italy (ISTAT Istituto Nazionale di Statistica - Italian Central Statistics Institute, 2013). Italy upholds a bank-based tradition. As opposed to Anglo-Saxon economies, bank-based ones, such as Germany (Ampenberger et al., 2013), Austria (Burgstaller \& Wagner, 2015), and Italy (Gottardo \& Moisello, 2014), are characterized by an underdeveloped stock market and extensive bank-customer relationship. European firms are more leveraged in countries where the stock market is less developed, and institutions favour creditor rights and ensure stricter law enforcement (Giannetti, 2003). Despite the poor quality of law enforcement in Italy (Giannetti, 2003), the widespread relationship lending between banks and firms mitigates creditor risk, thanks to contractual monitoring. Creditor risk can be further managed via other measures, such as rates of return, maturity, and collateral (Berger and Udell, 2002; Serrasqueiro et al., 2012; Burgstaller and Wagner, 2015). Hence, Italian private firms strongly rely on debt financing, as shown in Section 4, because of the impossibility of accessing the stock market and strict control and monitoring by banks. However, owing to the socioemotional orientation of Italian private family firms, namely their need for preserving the family business for future generations by retaining control and family influence, the results of this paper indicate that they are more willing than Italian private non-family firms to use debt and consequently abandon a zero-leverage policy. That occurs despite the presence of insignificant agency conflicts in Italian private family firms and also means that, for these family businesses, socioemotional considerations are more important than risk issues (Gottardo \& Moisello, 2014; Burgstaller \& Wagner, 2015).

The novelty of this contribution is that it uses a large sample of Italian private family and non-family firms, which thus operate within a single bank-oriented economy. That allows this empirical work, on the one hand, to neutralize the possible impacts of different country determinants on the zero-leverage choice and, on the other, to specifically take into account the incremental effect of being a family firm on the likelihood of eschewing a zero-leverage policy in a bank-based country (Italy), wherein, nevertheless, private firms generally and considerably use debt financing. The paper also explicitly considers the repercussions of the socioemotional wealth on the capital structure of Italian private family enterprises. It also permits a comparison between the orientation of family firms toward a zero-debt policy and that of their non-family peers. Therefore, this paper investigates the role of the "familiness" (Habberson \& Williams, 1999) in the context of the zero-leverage puzzle (Strabulaev \& Yang, 2013), by answering the following research questions: does Italian private firm propensity to be levered depend on family involvement? What dimensions of family involvement influence this propensity?

In doing so, the remainder of this paper is structured as follows. Section 2 provides a literature review and the hypothesis of the empirical research. It also clarifies how some aspects of the socioemotional wealth and corporate governance, applicable to Italian private family firms, cause agency conflicts to be insignificant and thus the use of leverage to be unrelated to these conflicts. Then, I examine the reasons why other features of the socioemotional wealth of the businesses being considered are likely to lead them to raise debt. Other determinants for a zero-debt policy are also studied. Section 3 describes the research method, whereas Section 4 presents the results and explains them. Section 5 concludes and provides some possible avenues for future investigation. It is worth noting that, where referring to "private family firms" or simply "family firms", the related concepts and arguments are deemed to be pertinent to Italian private family firms too, which is the objective of this paper.

\section{Theoretical Foundations and Hypothesis}

\subsection{Family Firms and Agency Conflicts: An Overview}

The mystery of zero-leverage firms, to use the words of Strabulaev and Yang (2013), has been examined in the background of family firms very rarely and only recently (Strabulaev \& Yang, 2013; Ramalho et al., 2018). This 
is quite surprising for at least two aspects, related to both the peculiar characteristics of family businesses and the possible presence of agency conflicts affecting them, thus creating a unique phenomenon which needs to be further investigated.

From the first standpoint, family firms are a very specific type of business, owing to their exclusive and complex specificities, concerning the influence of the beliefs, culture, views, and values of the family members on the business. Habberson and Williams (1999) define "familiness" as the unique bundle of resources a particular firm has because of the systems interaction between the family, its individual members, and the business. As such, family firms differ from their non-family counterparts in terms of corporate governance issues. In fact, family businesses are characterized by the concentration of ownership in a single person or among few people, in which the owners are actively involved in the management of a firm as managers and/or members of the board of directors and these businesses are run by a specific generation, i.e. that of the founder or later. Furthermore, both family and non-family firms have also non-economic objectives representing the dominant coalition; nonetheless the former have non-economic goals reflecting the sole interests of the controlling family, including its vision, attitudes, and intentions (Chrisman et al., 2012). In this respect, family firms strive to generate and preserve their socioemotional wealth, which is defined as a group of several elements, including identity, the ability to exercise family influence, and the perpetuation of a family dynasty (Gomez-Mejia et al., 2007). Socioemotional wealth creation and safeguard require autonomy and control, family cohesiveness, supportiveness, harmony, loyalty, pride, family name recognition, respect, status, goodwill in the community (Zellweger et al., 2011), the need to transfer the family business to future generations, and the need to sustain the family's image and reputation (Naldi et al., 2013).

Agency conflicts are created with the divergence of interests and asymmetric information existing between agents and principals. Hence, they can be produced by the separation of ownership and management (Ross, 1973), occur between owners and lenders (Myers, 1977; Smith \& Warner, 1979) or happen in the dominant-minority shareholder relationship (Mork et al., 1988). Agency conflicts and capital structure are correlated. The separation between ownership and management causes opportunistic managers to eschew debt, to moderate their undiversifiable employment risk (Amihud \& Lev, 1981), and to acquire perquisites. In fact, the absence of debt financing allows selfish managers to forego valuable and risky investment opportunities, and expropriate firm value, to the detriment of owners, as they only manage their "patient capital" (Zellweger, 2007). Therefore, debt use, thanks to the reduction of the free cash flow it can generate (Jensen, 1986), represents a tool that helps control managers. In fact, the latter are forced to create value to pay the interests on the outstanding debt and repay it punctually, thus preventing the firm's bankruptcy and the loss of their employment, wealth, and reputation. The agency problems between owners and lenders reveals that leverage allows opportunistic owners to implement behaviours, which favour them at the expense of creditors, such as overinvestment (Jensen \& Meckling, 1976) and/or underinvestment (Myers, 1977) conducts. When taking into account agency conflicts between majority and minority shareholders (Johnson et al., 2000), problems are created through the divergence between voting rights and cash flow rights, which is, in turn, obtained by appropriate strategies, such as dual class shares, pyramids, cross shareholdings (Villalonga et al., 2015), disproportionate board representation, and voting agreements that favour controlling shareholders. Agency conflicts between controlling and non-controlling shareholders are exacerbated by the use of debt, which strengthens the power of wealth expropriation on the part of majority owners.

Agency conflicts are likely to be negligible in family firms (Chrisman et al., 2004), and especially in private family-owned and -managed firms (Steijvers \& Niskanen, 2014). These assumptions are related to their socioemotional wealth orientation and effective corporate governance tools. All of these issues are explained in depth below.

\subsection{Agency Conflicts between Owners and Managers and Zero-Leverage Policy}

Agency conflicts between owners and managers (Berle \& Means, 1932; Jensen \& Meckling, 1976; Jensen, 1986) or Agency Problem I (Villalonga \& Amit, 2006) in family firms can be discussed through a twofold perspective: analysis of the situation of the first- versus later-generation family businesses. In the first generation, ownership and management usually concentrate on the founder and his/her nuclear family, and this coincidence between ownership and management mitigates agency problems between managers and owners (Blanco-Mazagatos et al., 2007). Furthermore, as family shareholders usually have blockholder ownership (Cheng, 2014), they have a strong incentive to effectively monitor managers (Demsetz \& Lehn, 1985; Shleifer \& Vishny, 1986; Villalonga et al., 2015) in the rare cases in which they are, obviously, not managers themselves. Lastly, in line with the socioemotional interpretation, when the family is the dominant coalition, the firm is more likely to engage in proactive stakeholder engagement activities, even when they offer no obvious financial returns. In this respect, 
family managers are closely identified with the firm's actions and tend to live in the community (Gómez-Mejia et al., 2011). That implies actions on the part of family managers that tend to improve cohesiveness, loyalty, and cooperation among all the stakeholders, especially between them and the owners. As Agency Problem I is negligible in first-generation family firms, owners do not need to employ leverage to prevent managers from selfishly using free cash flow (Jensen, 1986). Possible opportunistic managers are also not allowed to deliberately avoid debt in order to decrease their undiversifiable employment risk (Amihud \& Lev, 1981), since in such a case, they would be strongly controlled by family owners. Therefore, the zero- or positive-leverage behaviours are not influenced by presumed agency conflicts between owners and managers in first-generation family firms.

However, in later-generation family businesses, ownership and management become more dispersed and differentiated. Some family members may be both owners and managers, while others may simply be owners or may be neither owners nor managers. This may generate information asymmetries and the opportunistic behaviour of managers (Blanco-Mazagatos et al., 2007). In fact, owner-managers will be focused on the interests of their family branch and make decisions for the benefit of their own nuclear family, rather than for that of the family (firm) as a whole (Blanco-Mazagatos et al., 2016). Therefore, one could assume that leverage could prevent owner-managers from utilizing free cash flow to realize personal objectives (Jensen, 1986), to the detriment of non-manager family owners and their family branches. In fact, leverage provokes bankruptcy risk for a firm and, thus, presents a stronger incentive for owner-managers to recover the debt capital invested and to maximize the firm's value. Nonetheless, adequate governance mechanisms, such as direct control by non-manager owners, existence of board of directors and family governance mechanisms (for example, the family council mentioned by Villalonga et al., 2015), effectually discipline managers and, per se, cause agency conflicts between owner-managers and non-manager owners to be negligible in the later generations (Blanco-Mazagatos et al., 2016). To put it differently, the presence or absence of debt in later-generation family firms have no moderating effect on supposed agency conflicts between owner-managers and non-manager owners. Interestingly, Burgstaller and Wagner (2015) contend that presumed differences in agency costs across generations do not influence leverage, as capital structures do not differ between founder- and descendant-controlled family businesses.

\subsection{Agency Conflicts between Family Controlling and Non-Controlling Owners and Zero-Leverage Policy}

According to Villalonga et al. (2015), Agency Problem II (Villalonga \& Amit, 2006), or agency conflicts between majority and minority shareholders, is likely to overshadow Agency Problem I in family firms. Because of the divergence between control rights and cash flow rights, family controlling owners can expropriate wealth from non-controlling ones (Shyu \& Lee, 2009). Nevertheless, this kind of conflict of interest may not be frequent. Martin et al. (2017) document that minority shareholder-dominant family conflicts occur only under specific conditions; that is, when there is a family CEO, the founder is no longer involved and the firm's performance is poor. In fact, under these circumstances, the socioemotional wealth tends to be predominant compared to economic returns. However, Martin et al. (2017) examine publicly traded family businesses in the United States; therefore, it is not possible to infer that their results are also valid for private family firms. Yet, when considering private family businesses, the issue of the socioemotional orientation is expected to play a different and crucial role in explaining the reason why the agency conflicts being analysed are insignificant. Actually, owing to the considerable ownership by the family, private family firms have a much longer investment horizon and greater reputation concerns compared to private non-family businesses (Gedajlovic \& Carney, 2010; Steijvers \& Niskanen, 2014), thereby alleviating the agency conflicts between family controlling and non-controlling owners in private family-owned businesses. Thus, family controlling owners have no interest in using leverage to reinforce their power of rent extraction at the expense of non-controlling owners. Lastly, the presence of such minority owners in private family enterprises may be less common than in public family ones, due to their even more concentrated ownership. This point further justifies the irrelevance of debt financing in the background of agency conflicts between dominant family owners and minority owners in private family firms. Therefore, for the above-mentioned reasons, it is likely that the willingness of private family firms to enforce a zero-debt policy does not depend on the agency conflicts between family controlling shareholders and non-controlling ones.

\subsection{Agency Conflicts between Owners and Lenders and Zero-Leverage Policy}

Croci et al. (2011) and Dìaz-Dìaz et al. (2016) contend that agency conflicts between owners and lenders, that is Agency Problem III (Villalonga et al., 2015), are negligible in family businesses as opposed to their non-family counterparts. Family owners need to preserve the socioemotional wealth of their family firms, in terms of business perpetuation and family's image and reputation, and also wish to safeguard their concentrated and scarcely diversified investments. Consequently, family owners tend to behave fairly toward lenders, and hence 
creditors do not need to compensate for the strong possibility of selfish behaviours of shareholders by demanding higher interest rates, developing monitoring activities, and requiring bonding activities (Jensen \& Meckling, 1976). Furthermore, debt is also not interpreted by lenders as a tool for destroying their wealth, through, for example, overinvestment (Jensen \& Meckling, 1976) and/or underinvestment (Myers, 1977) activities. Therefore, the tendency to be levered does not depend on possible conflicts between owners and lenders in family enterprises.

\subsection{Research Hypothesis and Other Determinants for Zero-Leverage Policy}

The insignificant presence of agency conflicts in (Italian private) family firms implies that debt cannot be seen as an instrument in aligning the interests of managers with those of owners or used by selfish agents (owners or majority shareholders) to take advantage of their principals (lenders or minority shareholders, respectively). In other words, from an agency perspective, there is no linkage between (insignificant) agency conflicts in (Italian private) family firms and their debt policy, and hence between their (trivial) agency conflicts and their propensity to be debt-free or not. Moreover, this assertion is in line with the claims by Burgstaller and Wagner (2015), who observe that agency issues can be less important or solved by special relationships in family firms.

Nevertheless, several studies document that family firms prefer debt over equity when they finance their investments, whereas only few show a negative effect of family ownership on the employment of debt financing (Michiels \& Molly, 2017). Therefore, the possible stronger propensity of Italian private family firms to avoid a zero-debt policy, compared to their non-family counterparts, is likely to be driven by a motive, which is not related to agency conflicts. This motive concerns the need for maintaining control over the business in the long run, which represents an important dimension of family socioemotional wealth (Gottardo \& Moisello, 2014) and dominate risk considerations (Gottardo \& Moisello, 2014; Burgstaller \& Wagner, 2015). Hence, the following hypothesis will be empirically verified: Owing to the desire of family owners to keep long-term control over the business, and regardless of risk and agency considerations, Italian private family firms are more likely to use debt than their non-family peers.

Previous literature on capital structure has also established other factors that can have effects on the choice of the debt-equity mix of private firms and thus on the proclivity of these firms to be unlevered. These aspects refer to some of the most applied theories on the capital structure determinants, that is the trade-off (Kraus \& Litzenberger, 1973), pecking order (Myers, 1984; Myers \& Majluf, 1984), financial constraints, and financial flexibility (Dang, 2013; Bessler et al., 2013; Huang et al., 2017) approaches. These factors are used as control variables to account for several other theoretical facets, influencing the tendency to use zero debt on the part of private family and non-family firms.

According to the trade-off theory, firms set a target debt-equity ratio which is the point at which the marginal cost of bankruptcy of an increasing leverage is equal to its marginal benefit, due to tax advantages (Kraus \& Litzenberger, 1973). However, non-debt tax shields further help decrease income tax (Dammon \& Senbet 1988); therefore non-debt tax shields diminish the benefit of raising debt. As a result, businesses with higher corporate tax rates have a strong incentive to use debt. In contrast, the presence of non-debt tax shields decreases the need to raise it. Moreover, private firms suffer from higher information asymmetries, as compared to publicly listed firms, because they are not subject to stock exchange requirements and communication activities. Therefore, the risk perception concerning private firms is considerable for lenders, facing the consequences of an adverse selection (Stiglitz \& Weiss 1981). This drawback can be at least partially counterbalanced by firm size, as larger firms are often more diversified and thus bear a lower bankruptcy risk (Chen, 2004). Therefore, they can obtain debt capital more easily. Besides, lenders are also affected by a moral hazard problem, as usually they have no control over how the funds provided will be invested. This issue is particularly important for private firms, as they follow less stringent rules regarding reporting activities. Consequently, lenders may compensate for the risk they bear by requiring guarantees (Lopez-Gracia \& Aybar-Arias, 2000), so that the availability of tangible fixed assets, which are easy to collateralize and/or liquidate, favour debt access. In sum, the application of the trade-off theory for private firms predicts that their propensity to be unlevered is negatively related to the effective tax ratio, size, and tangibility of fixed assets and is positively associated with non-debt tax shields.

The pecking order theory represents an alternative approach to asymmetric information costs. On the basis of this approach to capital structure, investors (outside financiers), as opposed to managers and current shareholders (insiders), cannot correctly assess a firm's value and its future growth prospects (Myers, 1984; Myers \& Majluf, 1984). Hence, they tend to accept lower prices on new stock and bond issues relative to current market prices. As a result, firms prefer internal funds, and when external finance is needed, they will first issue debt, then hybrid forms of securities, such as convertible bonds, and will ultimately issue equity (Myers, 1984; Myers \& Majluf, 
1984) in order to minimize the costs of asymmetric information. The pecking order approach is also likely to apply to private firms, owing to their strong employment of bank debt (no access to capital markets), control retention (Holmes \& Kent, 1991), and opacity. In fact, these factors imply a similar hierarchy to the one described above, so that a private firm would firstly make use of retained earnings, then bank debt and, finally, equity issues (Sánchez-Vidal \& Martín-Ugedo, 2005). As a result, it is possible to affirm that the greater the profitability of a private firm is, the more likely its zero-leverage attitude is.

Financial constraints also exert an important effect on the adoption of a zero-debt policy (Huang et al., 2017). In fact, since lenders cannot effectively evaluate the quality of firms and their investments, they tend to ration credit. In other words, financial constraints cause firms to adopt a zero-leverage strategy (Devos et al., 2012). As previous research has demonstrated that constrained enterprises are usually small and young (Hadlock and Pierce, 2010), firm size and age are likely to be negatively related to a firm's propensity to use zero debt (Dang, 2013). Hence, a firm's size is interpreted as a control variable in both the background of trade-off theory and financial constraints.

Another explanation for zero-debt policy refers to the need to preserve financial flexibility. DeAngelo and DeAngelo (2007) contend that today's borrowing cost is the opportunity cost of an inability to borrow tomorrow; therefore, low leverage is desirable today because it provides the option to borrow tomorrow. Ferrão et al. (2016) add that the reduction of debt in the present creates conditions for the firm's future expansion. Consequently, firms will prefer to have very little debt today to maintain their debt capacity for financing tomorrow's investment opportunities (Dang, 2013). Consequently, the orientation to zero debt, to keep a debt capacity on the one hand, and the amount of intangible fixed assets, as a proxy for growth opportunities, and cash reserves, which decrease the need for acquiring debt financing on the other, should be positively related.

\section{Research Method}

The sampled firms are composed of Italian medium and large private family and non-family firms, belonging to all sectors except for the financial one. The choice of medium and large firms enables this work to rely on more consistent data from the point of view of the issues being investigated, whereas the selection of only non-financial businesses enables this research to avoid the effect of financial sector regulations and specific firms' financing policy (Gottardo \& Moisello, 2014). Furthermore, following previous studies (Anderson \& Reeb, 2003, Anderson et al., 2003; Barth et al., 2005; Amore et al., 2011; Croci et al., 2011; Dìaz-Dìaz et al., 2016), ownership is considered for identifying family firms. Specifically, similar to Ramalho et al. (2018) and depending on data availability, private family firms are referred to herein as those unlisted firms with one or more named individuals or families, jointly owning at least $50 \%$ of the equity. The use of the percentage of $50 \%$ for ownership depends on the fact that privately owned firms have concentrated ownership structures, therefore an ownership of 50\% is needed to achieve actual control (Amore et al., 2011). With regard to the issue of firm size, this work refers to the EU approach (European Commission Recommendation of 6 May 2003, concerning the definition of micro-, small-, and medium-sized enterprises). In particular, medium and large businesses in this study are considered to be those with revenues from sales and services (annual turnover) of at least EUR 10 million and at least 50 employees.

The sample data are gathered from the AIDA (Analisi Informatizzata Delle Aziende) database for the period of 2008-2017. AIDA is the Italian provider of the Bureau Van Dijk European Databases, containing comprehensive financial and accounting information on Italian companies in all sectors of activity. The initial sample includes all active non-financial Italian medium and large private family and non-family firms of the database, which are represented by 2,787 enterprises. Firms with missing observations and/or negative values for effective tax rates and/or leverage are excluded in order to avoid misleading results. Hence, the final sample consists of 1,595 private businesses, of which 1,071 are family and 524 non-family firms. All of the variables used in the empirical model concern book values and are described in detail in Table 1.

Table 1. Variable description and characteristic and expected sign

\begin{tabular}{ll}
\hline Variable & \multicolumn{1}{c}{ Definition } \\
\hline ZD* & $\begin{array}{l}\text { Zero-debt policy binary variable, taking the value of } 1 \text { if the firm has zero leverage and } 0 \text { otherwise in } \\
\text { a given year. }\end{array}$ \\
FDU* & $\begin{array}{l}\text { Family dummy, taking the value of } 1 \text { if the firm is a family one and } 0 \text { otherwise in a given year. } \\
\text { ETR* }\end{array}$ \\
& $\begin{array}{l}\text { Effective tax rate: total current, deferred, and prepaid income taxes over profit before taxation in a } \\
\text { given year. }\end{array}$ \\
NDT* & Non-debt tax shield: total depreciation, amortization, and writedowns over total assets in a given year.
\end{tabular}




\begin{tabular}{lll}
\hline TFA* & Tangible fixed assets: total tangible fixed assets over total assets in a given year. & Control variable \\
ROE & Return on equity: percentage of profit (loss) over the shareholder's funds in a given year. & Control variable \\
SIZE* $^{*}$ & Log of total assets in a given year. & Control variable \\
AGE* $^{*}$ & Age: number of years since the incorporation until 2017 in a given year. & Control variable \\
IFA* $^{*}$ Intangible fixed assets: total intangible fixed assets over total assets in a given year. & Control variable \\
TLF* $^{*}$ & Total liquid funds over total assets in a given year. & Control variable \\
\hline
\end{tabular}

Source: The variables and related definitions refer to those available on the AIDA database.

*Specifically, most of the variables being used are constructed on the basis of other variables, provided by the same database.

The effect of family control on the propensity to use zero debt is analysed by estimating the following logistic regression:

$$
Z D i, t=\beta_{0}+\beta_{1} F D U_{i, t}+\beta_{2} X_{i, t}+\varepsilon_{i, t}
$$

$\mathrm{ZD}_{\mathrm{i}, \mathrm{t}}$ is the measure of zero-debt of firm $i$ in year $t, \beta_{0}$ is the constant, $\mathrm{FDU}_{\mathrm{i}, \mathrm{t}}$ is the family variable of firm $i$ in year $t, \mathrm{X}_{\mathrm{i}, \mathrm{t}}$ is a vector of control variables for firm $i$ in year $t$, and $\varepsilon_{\mathrm{i}, \mathrm{t}}$ is an error term.

\section{Results}

The regression results for Italian private firms are shown in Table 2. Firstly, they confirm the previously stated hypothesis, because the relationship between FDU and ZD is negative and significant at the 1 per cent level. Therefore, Italian private family firms are more likely to use debt than their non-family counterparts, due to the desire of family owners to keep long-term control over the business, regardless of risk and agency considerations. This finding can be justified as follows. On the one hand, it is reasonable to contend that major agency conflicts of any kind are absent in Italian private family firms, because of their socioemotional wealth orientation, which favours fair relationships between managers and owners, family-controlling owners and non-controlling owners, and lenders and owners. In addition, blockholder ownership favours strict control on the part of owners toward managers in first-generation family enterprises, and adequate corporate governance mechanisms alleviate owner-manager and non-manager owner conflicts of interest in later-generation family firms. Hence, in this respect, debt is not related to insignificant agency conflicts in Italian private family firms; therefore, no relationship should be found between FDU and ZD. On the other hand, though, Italian private family enterprises are more inclined to employ debt than their non-family counterparts, as shown by the negative coefficient for FDU. This finding is attributed to the fact that family owners need to keep the business within the family and thus wish to exert long-term control over it without sharing the ownership with other non-family individuals. Interestingly, the mean debt-to-equity ratio, which was separately calculated, is considerable for both Italian private family and non-family businesses. Nonetheless, it is substantially higher for the private family firms (1.35) as opposed to the non-family ones (1.14). Thus, this evidence, supported by Gottardo and Moisello (2014) and Burgstaller and Wagner (2015), confirms that Italian private family firms reach higher levels of leverage to maintain control and family influence. This happens despite risk considerations (Gottardo \& Moisello, 2014; Burgstaller \& Wagner, 2015). Therefore, the importance of socioemotional wealth (control retention) prevails over risk aversion, and this view is also likely to motivate the preference among Italian private family firms for a zero-debt strategy, relative to their non-family peers. Remarkably, by considering a model of family-oriented particularistic behaviour (De Massis et al., 2014), it can be affirmed here that being a family business generates sufficient conditions for the idiosyncratic behaviour of Italian private family firms, compared to that of Italian private non-family ones. In fact, Italian private family firms are more likely to have a leveraged capital structure, due to their ability to raise debt, thanks to the discretionary power of the family to act, and their willingness to engage in a distinctive behaviour, in terms of adoption of a policy of socioemotional wealth creation.

The econometric outcomes also give support to the trade-off hypothesis, as the higher the ETR, the higher the probability for a firm to abandon a zero-leverage level to benefit from the tax advantage of debt. Again, in line with the trade-off theory, the coefficients for both SIZE and TFA are negative, implying that a greater firm's dimension that diminishes adverse selection problems and the availability of tangible fixed assets, which can be offered as a collateral and/or easily turned into cash, ease debt financing. However, NDT does not appear to be a strong motivation for the implementation of a zero-debt policy. The pecking order approach is also employed by the firms surveyed, as ROE is positively related to ZD. Therefore, more profitable enterprises can afford to use more retained earnings to finance their operations and thus are more likely to pursue a zero-debt policy. The financial constraints have a role in determining the orientation to a zero-debt choice, only when SIZE is taken into account, as bigger firms are likely to employ debt. In fact, AGE, despite the conjecture in this paper, exhibits a positive coefficient, as in Dang (2013). One interpretation for this fact can be found in the context of the 
pecking order theory. Specifically, Petersen and Rajan (1994) show that leverage decreases with age, as it is likely that older firms have accumulated more retained profits. La Rocca et al. (2011) document that, during a firm's life cycle, the debt is fundamental in the early stage of its development, while in the maturity stage it gradually substitutes debt for internal capital, thus following a hierarchical financial behaviour. Indeed, the pecking order view assumes a positive link between a firm's propensity to eschew debt and its age, since it can rely on reinvested earnings to finance its investments. Lastly, the financial flexibility issue is partly documented. In fact, while the relationship between IFA and ZD is not statistically significant, the connection between TLF and $\mathrm{ZD}$ is positive and statistically significant. This latter finding suggests that Italian private businesses employ considerable cash reserves to avoid using debt and, in turn, to maintain their ability to resort to debt financing in the future, in the event that they need it.

Table 2. Regression results

\begin{tabular}{|c|c|c|}
\hline Explanatory variable and controls & Predicted sign & Coefficient \\
\hline \multirow[t]{2}{*}{ constant } & & $-0.9788 * * *$ \\
\hline & & $(0.3556)$ \\
\hline \multirow[t]{2}{*}{ FDU } & - & $-0.2938 * * *$ \\
\hline & & $(0.0534)$ \\
\hline \multirow[t]{2}{*}{ ETR } & - & $-0.8421 * * *$ \\
\hline & & $(0.1508)$ \\
\hline \multirow[t]{2}{*}{ NDT } & + & 1.0125 \\
\hline & & $(1.3719)$ \\
\hline \multirow[t]{2}{*}{ TFA } & - & $-2.2628 * * *$ \\
\hline & & $(0.2082)$ \\
\hline \multirow[t]{2}{*}{ ROE } & + & $0.0046 * *$ \\
\hline & & $(0.0021)$ \\
\hline \multirow[t]{2}{*}{ SIZE } & - & $-0.2837 * * *$ \\
\hline & & $(0.0699)$ \\
\hline \multirow[t]{2}{*}{ AGE } & - & $0.0127 * * *$ \\
\hline & & $(0.0015)$ \\
\hline \multirow[t]{2}{*}{ IFA } & + & -0.7998 \\
\hline & & $(0.5038)$ \\
\hline \multirow[t]{2}{*}{ TLF } & + & $8.3532 * * *$ \\
\hline & & $(0.2078)$ \\
\hline
\end{tabular}

$\mathrm{R}^{2}: 0.2230$

Adjusted $\mathrm{R}^{2}: 0.2215$

Number of observations: 15950

Standard errors of coefficients are reported in parentheses.

$*, * *$, and $* * *$ indicate significance at the $10 \%, 5 \%$, and $1 \%$ levels, respectively.

Source: Personal elaboration, based on data available on the AIDA database.

\section{Conclusions}

Italian private family firms are more likely to use debt relative to their non-family counterparts, owing to the willingness of family owners to maintain long-term control and family influence over the business. Therefore, these socioemotional reasons, characterizing Italian private family firms, prevail over the issue of their risk aversion for debt financing.

At the same time, fair relationships between principals and agents in Italian private family firms, based on their socioemotional orientation, neither hinder, nor enhance their ability to pursue a zero-debt strategy. In other words, negligible agency conflicts in Italian private family businesses are unrelated to their employment of debt. Moreover, blockholder ownership and effective corporate governance mechanisms further help alleviate possible agency conflicts between owners and managers, particularly in the first- and later-generation family firms, respectively.

A possible development of this research may focus on comparisons between (private) family and non-family firms located in different countries, as it would be interesting to verify whether their orientation to zero-debt policies diverges and on what bases these differences, if any, can be explained in terms of their country determinants, such as legal, social, and financial drivers. 


\section{References}

Amihud, Y., \& Lev, B. (1981). Risk Reduction as a Managerial Motive for Conglomerate Mergers. The Bell Journal of Economics, 12(2), 605-617. https://doi.org/10.2307/3003575

Amore, M. D., Minichilli, A., \& Corbetta, G. (2011). How do managerial successions shape corporate financial policies in family firms? Journal of Corporate Finance, 17(4), 1016-1027. https://doi.org/10.1016/j.jcorpfin.2011.05.002

Ampenberger, M., Schmid, T., Achleitner, A. K., \& Kaserer, C. (2013). Capital structure decisions in family firms: Empirical evidence from a bank-based economy. Review of Managerial Sciences, 7(3), $247-275$. https://doi.org/10.1007/s11846-011-0077-2

Anderson, R. C., Mansib, S. A., \& Reeb, D. M. (2003). Founding family ownership and the agency cost of debt. Journal of Financial Economics, 68(2), 263-285. https://doi.org/10.1016/S0304-405X(03)00067-9

Anderson, R. C., \& Reeb, D. M. (2003). Founding-Family Ownership and Firm Performance: Evidence from the S\&P 500. Journal of Finance, 58(3), 1301-1328. https://doi.org/10.1111/1540-6261.00567

Barth, E., Gulbrandsen, T., \& Schøne, P. (2005). Family ownership and productivity: The role of owner-management. Journal of Corporate $\quad$ Finance, $1107-127$. https://doi.org/10.1016/j.jcorpfin.2004.02.001

Berger, A. N., \& Udell, G. F. (2002). Small business credit availability and relationship lending: The importance of bank organisational structure. Economic Journal, 112, F32-F53. https://doi.org/10.1111/1468-0297.00682

Berle, A., \& Means, G. (1932). The Modern Corporation and Private Property. New York: Mcmillan.

Bessler, W., Drobetz, W., Haller, R., \& Meier, I. (2013). The international zero-leverage phenomenon. Journal of Corporate Finance, 23(12), 196-221. https://doi.org/10.1016/j.jcorpfin.2013.08.004

Blanco-Mazagatos, V., de Quevedo-Puente, E., \& Castrillo, L. A. (2007). The Trade-Off Between Financial Resources and Agency Costs in the Family Business: An Exploratory Study. Family Business Review, 20(3), 199-213. https://doi.org/10.1111/j.1741-6248.2007.00095.x

Blanco-Mazagatos, V., de Quevedo-Puente, E., \& Delgado-García, J. B. (2016). How agency conflict between family managers and family owners affects performance in wholly family-owned firms: A generational perspective. Journal of Family Business Strategy, 7(3), 167-177. https://doi.org/10.1016/j.jfbs.2016.07

Burgstaller, J., \& Wagner, E. (2015). How do family ownership and founder management affect capital structure decisions and adjustment of SMEs? Evidence from a bank-based economy. Journal of Risk Finance, 16(1), 73-101. https://doi.org/10.1108/JRF-06-2014-0091

Carney, M., Van Essen, Gedajlovic, E. R., \& Heugens, P. P. M. A. R. (2015). What Do We Know About Private Family Firms? A Meta-Analytical Review. Entrepreneurship Theory and Practice, 39(3), 513-544. https://doi.org/10.1111/etap.12054

Chen, J. J. (2004). Determinants of capital structure of Chinese-listed companies. Journal of Business Research, 57(12), 1341-1351. https://doi.org/10.1016/S0148-2963(03)00070-5

Cheng, Q. (2014). Family firm research - A review. China Journal of Accounting Research, 7(3), $149-163$. https://doi.org/10.1016/j.cjar.2014.03.002

Chrisman, J. J., Chua, J. H., \& Litz, R. A. (2004). Comparing the Agency Costs of Family and Non-Family Firms: Conceptual Issues and Exploratory Evidence. Entrepreneurship Theory and Practice, 335-354. https://doi.org/10.1111/j.1540-6520.2004.00049.x

Chrisman, J. J., Chua, J. H., Pearson, A. W., \& Barnett, T. (2012). Family Involvement, Family Influence, and Family-Centered Non-Economic Goals in Small Firms. Entrepreneurship Theory and Practice, 36(2), 267-293. https://doi.org/10.1111/j.1540-6520.2010.00407.x

Croci, E., Doukas, J. A., \& Gonenc, H. (2011). Family Control and Financing Decisions. European Financial Management, 17(5), 860-897. https://doi.org/10.1111/j.1468-036X.2011.00631.x

Dang, V. A. (2013). An empirical analysis of zero-leverage firms: New evidence from the UK. International Review of Financial Analysis, 30(5), 189-202. http://dx.doi.org/10.1016/j.irfa.2013.08.007

Dammon, R. M., \& Senbet, L. W. (1988). The Effect of Taxes and Depreciation on Corporate Investment and Financial Leverage. Journal of $\quad$ Finance, $453-373$. https://doi.org/10.1111/j.1540-6261.1988.tb03944.x 
DeAngelo, H. \& DeAngelo, L. (2007). Capital Structure, Payout Policy, and Financial Flexibility. Marshall School of Business. Working Paper No. FBE 02-06. Retrieved from https://ssrn.com/abstract=916093.

De Massis, A., Kotlar, J., Chua, J. H., \& Chrisman, J. J. (2014). Ability and Willingness as Sufficiency Conditions for Family-Oriented Particularistic Behaviour: Implications for Theory and Empirical Studies. Journal of Small Business Management, 52(2), 344-364. https://doi.org/10.1111/jsbm.12102

Demsetz, H., \& Lehn, K. (1985). The Structure of Corporate Ownership: Causes and Consequences. Journal of Political Economy, 93(6), 1155-1177.

Devos, E., Dhillon, V., Jagannathan, M., \& Krishnamurthy, S. (2012). Why are firms unlevered? Journal of Corporate Finance, 18(3), 664-682. https://doi.org/10.1016/j.jcorpfin.2012.03.003

Díaz-Díaz, N. L., García-Teruel, P. J., \& Martínez-Solano, P. (2016). Debt maturity structure in private firms: Does the family control matter? Journal of Corporate Finance, 37, 393-411. https://doi.org/10.1016/j.jcorpfin.2016.01.016

European Commission Recommendation of 6 May 2003. Retrieved from https://eur-lex.europa.eu/LexUriServ/LexUriServ.do?uri=OJ:L:2003:124:0036:0041:EN:PDF

Ferrão, J., Curto, J. D., \& Gama, A. P. (2016). Low-leverage policy dynamics: An empirical analysis. Review of Accounting and Finance, 15(4), 463-483. https://doi.org/10.1108/RAF-09-2015-0135

Gedajlovic, E., \& Carney, M. (2010). Market, hierarchies and families: Toward a transaction cost theory of the family firm. Entrepreneurship Theory and Practice, 34(6), 1145-1171. https://doi.org/10.1111/j.1540-6520.2010.00418.x

Giannetti, M. (2003). Do better institutions mitigate agency problems? Evidence from corporate finance choices. Journal of Financial Quantitative Analysis, 38(1), 185-212. https://doi.org/10.2307/4126769

Gómez-Mejia, L. R., Takacs-Haynes, K., Nuñez-Nickel, M., Jacobson, K. J. L., \& Moyano-Fuentes, J. (2007). Socioemotional wealth and business risks in family-controlled firms: Evidence from Spanish olive oil mills. Administrative Science Quarterly, 52(1), 106-137. https://doi.org/10.2189/asqu.52.1.106

Gómez-Mejia, L. R., Cruz, C., Berrone, P., \& De Castro, J. (2011). The Bind that Ties: Socioemotional Wealth Preservation in Family Firms. Academy of Management Annals, 5(1), 653-707. https://doi.org/10.1080/19416520.2011.593320

Gottardo, P., \& Moisello, A. M. (2014). The capital structure choices of family firms. Evidence from Italian $\begin{array}{llll}\text { medium-large unlisted firms. } & \text { Managerial Finance, }\end{array}$ https://doi.org/10.1108/MF-03-2013-0065

Habbershon, T. G., \& Williams, M. L. (1999). A Resource-Based Framework for Assessing the Strategic Advantages of Family Firms. Family Business Review, 12(1), 1-25. https://doi.org/10.1111/j.1741-6248.1999.00001.x

Hadlock, C. J., \& Pierce J. R. (2010). New Evidence on Measuring Financial Constraints: Moving Beyond the KZ Index. The Review of Financial Studies, 23(5), 1909-1940. https://doi.org/10.1093/rfs/hhq009

Holmes, S., \& Kent, P. (1991). An Empirical Analysis of the Financial Structure of Small and Large Australian Manufacturing Enterprises. The Journal of Entrepreneurial Finance, 1(2), 141-154.

Huang, Z., Li, W., \& Gao, W. (2017). Why do firms choose zero-leverage policy? Evidence from China. Applied Economics, 49(28), 2736-2748. https://doi.org/10.1080/00036846.2016.1245845

ISTAT - Istituto Nazionale di Statistica (Italian Central Statistics Institute) (2013). Chapter 2 - Il sistema delle imprese italiane: Competitività e potenziale di crescita. Retrieved from http://www.istat.it/it/files/2013/05/cap2.pdf.

Jensen, M. C. (1986). Agency Costs of Free Cash Flow, Corporate Finance, and Take-overs. American Economic Review, 76(2), 323-329. https://doi.org/10.2307/1818789

Jensen, M. C., \& Meckling, W. H. (1976). Theory of the firm: managerial behaviour, agency costs and ownership $\begin{array}{llll}\text { structure. Journal of } & \text { Financial }\end{array}$ https://doi.org/10.1016/0304-405X(76)90026-X

Johnson, S., La Porta, R., Lopez-De-Sinales, F., \& Shleifer, A. (2000). Tunnelling. American Economic Review, 90(2), 22-27. https://doi.org/10.1257/aer.90.2.22

Kraus, A., \& Litzenberger, R. H. (1973). A State-preference Model of Optimal Financial Leverage. Journal of 
Finance, 28(4), 911-922.

La Rocca, M., La Rocca, T., \& Cariola, A. (2011). Capital structure decisions during a firm's life cycle. Small Business Economics, 37(1), 107-130. https://doi.org/10.1007/s11187-009-9229-z

Li, W., Huang, Z., \& Gao, W. (2015). Does Zero-leverage Policy Increase Inefficient Investment? From The Perspective Of Lack Of Bank Creditors. The Journal of Applied Business Research, 31(6), $2237-2252$. https://doi.org/10.19030/jabr.v31i6.9480

Lopez-Gracia, J., \& Aybar-Arias, C. (2000). An empirical approach to the financial behaviour of small and medium sized companies. Small Business Economics, 14, 55-63. https://doi.org/10.1023/A:1008139518709

Martin, G., Gómez-Mejıa L. R., Berrone, P., \& Makri M. (2017). Conflict Between Controlling Family Owners and Minority Shareholders: Much Ado About Nothing? Entrepreneurship Theory and Practice, 41(6), 999-1027. https://doi.org/10.1111/etap.12236

Michiels, A., \& Molly, V. (2017). Financing Decisions in Family Businesses: A Review and Suggestions for Developing the Field. Family Business Review, 30(4) 369-399. https://doi.org/10.1177/0894486517736958

Myers, S. C. (1977). Determinants of Corporate Borrowing. Journal of Financial Economics, 5(2), $147-175$. https://doi.org/10.1016/0304-405X(77)90015-0

Myers, S. C. (1984). The Capital Structure Puzzle. Journal of Finance, 39(3), 575-592. Retrieved from https://www.jstor.org/stable/2327916

Myers, S. C., \& Majluf N. S. (1984). Corporate Financing and Investment Decisions When Firms Have Information That Investors Do Not Have. Journal of Financial Economics, 13(2), 187-221. https://doi.org/10.1016/0304-405X(84)90023-0

Naldi, L., Cennamo, C., Corbetta, G., \& Gomez-Mejia, L. (2013). Preserving Socioemotional Wealth in Family Firms: Asset or Liability? The Moderating Role of Business Context. Entrepreneurship Theory and Practice, 37(6), 1341-1360. https://doi.org/10.1111/etap.12069

Petersen, M. A., \& Rajan R. G. (1994). The Benefits of Lending Relationships: Evidence from Small Business Data. Journal of Finance, 49(1), 3-37. https://www.jstor.org/stable/2329133

Ramalho, J. S., Rita, R. M. S, \& da Silva, J. V. (2018). The impact of family ownership on capital structure of firms: Exploring the role of zero-leverage, size, location and the global financial crisis. International Small Business Journal: Researching Entrepreneurship, https://doi.org/10.1177/0266242617753050

Rapp, M. S., Schmid, T., \& Urban, D. (2014). The value of financial flexibility and corporate financial policy. Journal of Corporate Finance, 29, 288-302. http://dx.doi.org/10.1016/j.jcorpfin.2014.08.004

Ross, S. (1973). The economic theory of agency: The principal's problem. American Economic Review, 63, 134-139.

Sánchez-Vidal, J., \& Martín-Ugedo, J. F. (2005) Financing Preferences of Spanish Firms: Evidence on the Pecking Order Theory. Review of Quantitative Finance and Accounting, 25(4), 341-355. https://doi.org/10.1007/s11156-005-5459-6

Serrasqueiro, Z., Nunes, P. M. \& da Silva, J. V. (2012). Are financing decisions of family-owned SMEs different? Empirical evidence using panel data. Journal of Management and Organization, 18(3), $363-382$. https://doi.org/10.1017/S1833367200000857

Shleifer, A., \& Vishny, R. W. (1986). Large Shareholders and Corporate Control. Journal of Political Economy, 94(3), 461-488. https://doi.org/10.1086/261385

Shyu, Y. W., \& Lee, C. I. (2009). Excess Control Rights and Debt Maturity Structure in Family-Controlled Firms. Corporate Governance: An International Review, 17(5), 611-628. https://doi.org/10.1111/j.1467-8683.2009.00755.x

Smith, C., \& Warner, J. (1979). On financial contracting: An analysis of bond covenants. Journal of Financial Economics, 7, 117-161. https://doi.org/10.1016/0304-405X(79)90011-4

Steijvers, T., \& Niskanen, M. (2014). Tax aggressiveness in private family firms: An agency perspective. Journal of Family Business Strategy, 5(4), 347-357. http://dx.doi.org/10.1016/j.jfbs.2014.06.001

Stiglitz, J. E., \& Weiss, A. (1981). Credit Rationing in Markets with Imperfect Information. The American Economic Review, 71(3), 393-410. 
Strebulaev, I., \& Yang, B. (2013). The mystery of zero-leverage firms. Journal of Financial Economics, 109(1), 1-23. https://doi.org/10.1016/j.jfineco.2013.02.001

Villalonga, B., \& Amit, R. (2006). How do family ownership, control and management affect firm value? Journal of Financial Economics, 80(2), 385-417. http://dx.doi.org/10.1016/j.jfineco.2004.12.005

Villalonga, B., Amit, R., Trujillo, M. A., \& Guzmán, A. (2015). Governance of Family Firms. Annual Review of Financial Economics, 7, 635-654. https://doi.org/10.1146/annurev-financial-110613-034357

Zellweger, T. (2007). Time Horizon, Costs of Equity Capital, and Generic Investment Strategies of Firms. Family Business Review, 20(1), 1-15. https://doi.org/10.1111/j.1741-6248.2007.00080.x

Zellweger, T. M., Nason, R. S., Nordqvist, M., \& Brush, C. G. (2011). Why Do Family Firms Strive for Nonfinancial Goals? An Organizational Identity Perspective. Entrepreneurship Theory and Practice, 37(2), 229-248. https://doi.org/10.1111/j.1540-6520.2011.00466.x

\section{Copyrights}

Copyright for this article is retained by the author(s), with first publication rights granted to the journal.

This is an open-access article distributed under the terms and conditions of the Creative Commons Attribution license (http://creativecommons.org/licenses/by/4.0/). 